\title{
KAPCSOLATDINAMIKAI FOLYAMATELEMZÉS PROCESSZOMETRIÁVAL SINE MORBO ÉS KLINIKAI ESETEKBEN
}

\author{
BAGDY EMŐKE \\ Károli Gáspár Református Egyetem Pszichológiai Intézete \\ E-mail: info@bagdyemoke.hu \\ Beérkezett: 2020. február 28. - Elfogadva: 2020. február 29.
}

Célkitûzés: A processzometria módszerének alkalmazását bemutatni párok kapcsolatdinamikai folyamatainak követésében.

Módszer: A Közös Rorschach Vizsgálat (KRV) textusfeldolgozásának validált eljárása, amely a teszt jegyzókönyv interakcióinak folyamatán át módot ad a páratlanul egyszeri kapcsolati viszonyminták „komputertomográfiás", rétegeire bontott, finom elemzésére. A feldolgozás objektív módszertani oldala a számítógépes folyamatmonitorozás, a vizsgált három dimenzióban (dominancia, együttmúködési aktivitás és intimitás), ötfokozatú skálán. Interpretatív elemzési oldala az üzenettartalmak szimbolikus jelentések mentén történô összefüzése. A kommunikáció „hogyanja” és üzeneti tartalma („,mit üzen” a v. sz.) együttesen a lelki mélységet bevilágító felismerésekhez segítenek hozzá.

Eredmények: A feldolgozott két esetet bemutató tanulmány, egy látszólag sine morbo pár "fallikus kollúziója”, valamint egy anorexia nervosában szenvedố lánynak édesanyjával való mély, lelki dinamikai azonossága arra nézve, hogy egy nônek veszélyes felnôtté válnia. Titkos összejátszásuk közös nevezôje: „maradjunk kislányok".

Konklúzió: A tanulmány lehetôséget ad az elemzés lépéseinek és munkamódjának megismerésére. Rávilágít a KRV pár-és családdiagnosztikai jelentőségére a (rejtett) kapcsolatdinamikai történések megismerésében.

Kulcsszavak: Közös Rorschach Vizsgálat (KRV); processzometria, fallikus kollúzió, anorexia nervosa 


\section{BEVEZETÉS ${ }^{1}$}

A Közös Rorschach Vizsgálat (KRV) jegyzôkönyveinek módszertanilag új feldolgozási lehetôsége a processzometria. Azt a sajátosságát ragadja meg a kommunikációnak, amely a cirkulárisasban (visszatérô, jellegzetes viszonymintákban) a kapcsolat fenntartásának „hogyanját” tükrözi. Ugyanakkor az üzenettartalmak szimbolikus nyelvén gyakorta felszínre hoz rejtett szükségleti tartalmakat, elrejtett (vagy rejteni szándékolt) érzelmeket, indulatokat. Ha mindkét szinten elmélyülünk az interakciókban, többet tudhatunk meg a vizsgált személyek kapcsolatáról, mint amire ók rá tudnak látni, és amiként képesek volnának értelmezni helyzetüket. A processzometria számítógépes programja (Bagdy E., Vetier, A., Csákvári Zs., Kiss D., Vargha, A., Bánsági, P, 2006) lehetôvé teszi a pontos feldolgozást, a kimunkált eljárásban (Bagdy és mtsai, 2006) az interakciók (ötfokozatú rendszerben) „fokolásának” precíz kivitelezését, így a vizsgált három dimenzióban (dominancia vs. dependencia; az együttmúködést elôsegítô vs. gátló aktivitás, végül a pozitív érzelmi vs. negatív, elutasító emocionális üzenetek intimitásszintjén) a viszony folyamati jellegzetességeinek követését, diagramokban is nyomon követését. A processzometria értékeit két eset elemzésén át szeretnénk bemutatni. Megjegyezzük, hogy a jelölési rendszer online közvetlenül elérhetô, letölthetô az internetes családdiagnosztikai tankönyvünkból: http:// www.webcreator.hu/ tankonyv, amely a módszer validitásvizsgálati eredményeit is tartalmazza.

Tanulmányunk célja a módszer információs értékének bemutatása a gyakorlati felhasználásban. Rávilágítunk arra:

1. miként bontható ki, ismerhetô fel egy - látszólag adaptív életvezetésú - pár kapcsolatában a tudattalan összejátszás (kollúzió); valamint

2. klinikai esetben hogyan találhatunk rá a kapcsolati dinamika követésén át a patológia létrejöttét aktiváló és fenntartó „rejtett mozgatóra”, miként tükrözôdik egy anya és lánya kapcsolatában a tudattalan szükségletek által indukált szövetség (Willi, 1978). Eseteink elemzésében a folyamatdinamikának (rejtett kapcsolati erốk harcának és kimenetelének) a nyomon kísérése a célunk, hogy ráláthassunk a diádikus kapcsolatok mögöttes világára.

Ismertetésünkben a processzometriai munka fázisai szerint haladunk. Ezek:

1. A KRV felvétele, jegyzôkönyvben rögzítése (másodlagos viszonymeghatározó jegyek kiemelése).

2. Jelölés és (számítógépes) kiértékelés.

3. A kapott eredmények elemzése: a három dimenzió viszonykonstellációinak kibontása.

4. A projektált üzenettartalmak interpretációja (a konzultációs vagy terápiás kérdésfeltevés nyomán ez specifikus klinikai feladat).

5. Összegzô vélemény alkotása.

Az írás a 2005-ben, egyetemi kutató munkánkat bemutató kiadványban (Bagdy E., Mirnics Zs., Vargha A. [2005]. Egyén-pár-család. Budapest: Animula) leírt egyik esettanulmányunk átdolgozott változata. 
Az elemzés a három dimenzióban mért viszonymintázat összefüggéseire fókuszol, és arra a kérdésre válaszol, hogyan folyik a kommunikáció a felek között. Az értelmezó munka az üzenettartalmak (Rorschach) szimbolikája, jelentéskeretei közt a Rorschach -tábla felszólító jellegével összefüggésben desifrírozza a választartalmakat. Ez a szint gyakorta kihagyható, csupán a nyilvánvalóan kivilágló tartalmak interpretációjára redukálható. A klinikai munkához azonban (segítô szakembernek, családkonzultációs és/vagy terápiás munkát végzônek) mindenképpen javasoljuk ezt a munkaszintet. Természetesen egyéni Rorschach- (alapfokú) jártasság elegendô hozzá, csupán a tartalmak jelentéskörének elsajátítására van feltétlenül szükség.

\section{ELSŐ ESET: FALLIKUS KOLLÚZIÓ EGY PÁRKAPCSOLATBAN}

Elsố esetelemzésünk sine morbo (= betegség nélküli), azaz jól funkcionáló párkapcsolat. A ,jól funkcionálót” azonban idézôjelbe kell tennünk. Még élhetô köteléken belül olyan világ tárul fel előttünk, amelyben a pár életének egyensúlya kényes, törékeny, ingatag.

A párral önkéntes ajánlkozásuk nyomán találkoztunk. Közös Rorschach Vizsgálatokhoz kerestünk olyan jelentkezóket, akik 5-10 éve élnek együtt, és kapcsolatukat megfelelőnek tartják („kielégítô”, „megfelelő”, „nincs krízishelyzet”). A pár férfitagja értesített arról, hogy készek egy kapcsolatvizsgálatra, és beleegyezésüket adják anyaguk tudományos célokra történô felhasználásához. Késôbb kiderült, hogy a felesége az ajánlkozásról nem tudott, de nem tiltakozott ellene. Az ó egyetlen kérdése ez volt az elôzetes megegyezés idejen: „Ugye szólnak, ha valami nagy bajt vesznek észre nálunk?” Ezt követôen közös megegyezéssel létrejött a vizsgálati helyzet.

Ádám és Éva (nevezzük ôket így) a „bemelegítô” interjú során sajátos viszonyról adott benyomásszerú képet. Feltúnt Éva kiélezô stílusa, nyelvi kihegyezettsége, egyet nem értési készsége, replikázó hajlama. Indulatilag is dinamizáltabb volt a férjénél. A férfi kevésbé volt aktív a kapcsolatuk bemutatásában, fékezô stílust, visszafogottabb viselkedést mutatott.

Könnyen vitába bonyolódtak. Benyomásszinten a „két dudás egy csárdában” szimmetrikus-versengô viszonyminta látszott jellemzôjüknek, csupán a férfi hôfokszegényebb viszonyulása gyengítette a versengés egyik oldalát.

Kiderült, hogy tíz éve házasok. Gyermektelenek. Értelmiségi diplomások. Éva 32, Ádám 36 éves. Egyetemi éveik alatt kerültek össze. Noha szerelmi házasság volt, sok összezördülést, vitát hordozott. Kölcsönösen egymást tartották kompromisszumképtelennek. Mindezek ellenére „élhetônek” mondták kapcsolatukat, melyból hiányzott a gyermek. Éva egyetemi évei alatt nem vállalta, késôbb pedig a sok egzisztenciális teher észrevétlenül vitte el az éveket. Mire lakáshelyzetüket megoldották, munkahelyi viszonyaikat elrendezték, nyaralóba befektettek, autó(ka)t vettek, utazgattak, az idô elrepült. Kapcsolatukban „sok a bonyodalom”, mondták, a gyermekkérdés miatt is. Mélyebbre az exploratív interjúhelyzetben nem merészkedtünk. Ígéretet bármiféle viszszajelentésról nem tettünk (a vizsgálat végeztével mégis jeleztük, hogy köszönetünket azzal is szeretnénk kifejezni, ha valaha szükségét érzik pszichológussal történô megbeszélésnek, konzultációnak, akkor készséggel teszünk javaslatot, kihez forduljanak). 
Életciklus szempontjából egyedileg (Erikson nyomán) a generativitás szakaszában vannak, szakmai önrealizáció, család, gyermek, az élet alkotó kiteljesítése a feladat, szemben a stagnálással, mely esetükben a gyermek hiánya miatt parciálisan érvényes volt. A családciklus szempontjából „fáziskésés” mutatkozott. A házasságkötéstốl a gyermekvállalásig terjedố idốszak kitolódott. Ennek nyomán megfogalmazódott az a kérdés: „Mi az életük értelme? Merre tartanak?” A diád pangó párhelyzete a potenciális krízis veszélyét sugallja: „Egy szó elég, s nem lesz mentség se vulkán pörölye, se Adonisz varázsa aztán ha egyszer halálos szerelemre gyúltok.” Louise Labé (1944) versének soraival jelezzük azt a veszélyt, amely a (gyermekben beteljesülô) hiányzó harmadik esetén gyakorta elóáll. Nincs közös harmadik, beléphet a külsô személy, aki vihart keltve söpri el a diád szövetségét.

A Közös Rorschach Vizsgálathoz folyamodva az alábbi „közös alkotást” kaptuk, melyet ezúttal már kódjelekkel ellátva (lejelölve) mutatunk be. (Felhívjuk rá a figyelmet, hogy érdemes a dialógust egyszer végigolvasni, kellố figyelemmel, nyitott, befogadó lélekkel. Ha van rá rezdüló asszociációnk, jegyezzük fel egy lapra, mielôtt az elemzés olvasását megkezdenénk.)

1. táblázat. KRV jegyzôkönyv (Ádám és Éva)

ssz. tbl. nem jel-1

$\begin{array}{llll}1 & 1 & 1 & \text { IJ } \\ 2 & 1 & 2 & \text { UJ } \\ 3 & 1 & 1 & \text { SI } \\ & & & \\ 4 & 1 & 2 & \text { ELL } \\ 5 & 1 & 1 & \text { STOV } \\ & & & \\ 6 & 1 & 2 & \text { ELL } \\ 7 & 1 & 1 & \text { TK } \\ 8 & 1 & 2 & \text { ELL }\end{array}$

$\begin{array}{llll}9 & 1 & 1 & \text { STOV }\end{array}$

$\begin{array}{llll}10 & 1 & 2 & \text { ELL }\end{array}$

$\begin{array}{llll}11 & 1 & 1 & \text { TK }\end{array}$

$\begin{array}{llll}12 & 1 & 2 & \text { SI }\end{array}$

\section{jel-2 szöveg}

RPO Én erre azt mondtam, hogy ez egy fekete róka. (ránéz)

Én meg azt, hogy szarvasbogár.

T Micsoda??? Akkor ez egy fekete róka. (nyújtja felém)

KR Nem! Lófütty neked!

De mi az, hogy szarvasbogár? Nézd meg, itt a szeme, itt az orra.

Jó, hát az neked, de nekem meg ez jött ki.

RPO És akkor ezzel mit csinálsz? (ránéz)

RPO Hát azt kihagyom. És akkor ez mi, ha ez a szeme? Ez mondjuk rókaorr, rendben van, de a füle az se áll így ki. Ádám, szóval ilyen alapon ez nem róka. (ránéz)

MK Zsákutcába fogunk így jutni, én úgy érzem. Az, hogy inkább róka, az nem azt jelenti, hogy fixen, de még akkor is ez fehér pofafoltnak betudható, ez meg fülszốrnek. Oké?

De nem, akkor sem.

És ha ez itt szarvasbogár, akkor ez itt mi rajta, ez a sok rengeteg?

Jó, nekem ez látszott belóle. 
$\begin{array}{llll}13 & 1 & 1 & \text { FV }\end{array}$

$\begin{array}{llll}14 & 1 & 2 & \text { FV } \\ 15 & 1 & 1 & \text { UJ } \\ 16 & 1 & 2 & \text { ELL } \\ 17 & 1 & 1 & \text { ELL } \\ & & & \\ 18 & 1 & 2 & \text { BIZT } \\ 19 & 1 & 1 & \text { NULL }\end{array}$

$\begin{array}{llll}20 & 1 & 2 & \text { FV } \\ 21 & 1 & 1 & \text { UJ } \\ & & & \\ 22 & 1 & 2 & \text { MEGJ } \\ 23 & 1 & 1 & \text { STOV } \\ 24 & 1 & 2 & \text { ELL }\end{array}$

$\begin{array}{llll}25 & 1 & 1 & \text { KOMP }\end{array}$

$\begin{array}{llll}26 & 1 & 2 & \text { DOKRE }\end{array}$

$\begin{array}{llll}27 & 1 & 1 & \text { USZJNEI }\end{array}$

$\begin{array}{llll}28 & 2 & 2 & \text { IJ }\end{array}$

$\begin{array}{llll}29 & 2 & 1 & \mathrm{UJ}\end{array}$

$\begin{array}{llll}30 & 2 & 2 & \text { USZNNEI }\end{array}$

$\begin{array}{llll}31 & 3 & 2 & \text { IJ }\end{array}$

$\begin{array}{llll}32 & 3 & 1 & \text { TK }\end{array}$

$\begin{array}{llll}33 & 3 & 2 & \text { TM }\end{array}$

$\begin{array}{llll}34 & 3 & 1 & \mathrm{UJ}\end{array}$

$\begin{array}{llll}35 & 3 & 2 & \mathrm{UJ}\end{array}$

$\begin{array}{llll}36 & 3 & 1 & \text { KTOV }\end{array}$

$\begin{array}{llll}37 & 3 & 2 & \text { DO }\end{array}$

$\begin{array}{llll}38 & 3 & 1 & \text { SI }\end{array}$

$\begin{array}{llll}39 & 3 & 2 & \text { USZJNEI }\end{array}$
Nálam zavaró az 1/10-ed része a rajznak, neked a 2/3-ad része. Konszenzusra kell jutnunk? (hozzám)

Mindenképpen?

Akkor maradjunk abban, hogy egy szürke paca, szerintem tengelyesen tükrözve.

KR Nem róka, az biztos, szívem, egy róka az nem ilyen.

KR Ellenben egy szarvasbogár az pont ilyen, ezt a képet találom meg a határozóban. (ironikusan)

Akkor találjunk valami harmadikat.

RPO Nincs harmadik. Most mért? Harmadik elôbb eszembe jutott volna, azt mondanám most a róka helyett. (ránéz)

Próbáld így nézni, és függetlenítsd el a rókától. Jó, egy Action Man múanyag bábu szürkére festve, széthajtott állapotban.

KR Ádám, ne legyél már ilyen.

Itt van a két lába, itt vannak a kezei.

KR De most, ha megkötöd magad, akkor semmi értelme végigcsinálni. Ez nem róka.

Szerintem ez egy szarvasbogár. Várjál, nôstény vagy hím? (nagyon ironikusan)

Nôstény.

Szerintem ez egy nôstény szarvasbogár. És most volt a 10. évfordulónk.

RPO Én erre azt mondtam, hogy busóálarc, itt a szakálla, szarva, szemüvege, orra. (ránéz)

Én meg azt mondtam, két törpe összerúg, és vérzik a bokájuk.

Ezt elfogadom.

Ez így egy béka, én azt mondom.

Hol béka?

Itt van a szeme, mellsố lába.

Ha föntrôl nézzük, akkor ez egy szitakötőlárva.

RPO Jó, én meg azt mondtam, hogy két pincér az asztalra leteszi a terítôt. (ránéz)

Két néger gádzsi a kondér fölött kavar.

Hát akkor ez végül is közelített. Két nô, kész.

Leszbikusok, mert az érzelmek is szikráznak közöttük. De így tényleg olyan, mint egy szitakötôlárva, hibátlanul.

Na, két nô, jó? Mert azt mind a ketten láttuk benne. 


$\begin{array}{llll}40 & 4 & 2 & \text { IJ } \\ 41 & 4 & 1 & \text { ELL } \\ 42 & 4 & 2 & \text { BIZT } \\ 43 & 4 & 1 & \text { UJ } \\ 44 & 4 & 2 & \text { ELL } \\ & & & \\ 45 & 4 & 1 & \text { FV } \\ & & & \\ 46 & 4 & 2 & \text { MEGJ } \\ & & & \\ 47 & 4 & 1 & \text { DOK } \\ & & & \\ & & & \\ 48 & 4 & 2 & \text { USZJNEI } \\ 49 & 5 & 2 & \text { IJ } \\ 50 & 5 & 1 & \text { USZJNEI } \\ & & & \\ & & & \\ 51 & 6 & 1 & \text { IJ } \\ 52 & 6 & 2 & \text { KTOV } \\ 53 & 6 & 1 & \text { USZJNEI } \\ 54 & 7 & 2 & \text { IJ } \\ 55 & 7 & 1 & \text { UJ }\end{array}$

$\begin{array}{cccl}56 & 7 & 2 & \text { SI } \\ 57 & 7 & 1 & \text { USZJI } \\ 58 & 8 & 2 & \text { IJJ } \\ 59 & 8 & 1 & \text { UJ }\end{array}$

$\begin{array}{llll}60 & 8 & 2 & \text { HEJ }\end{array}$

$\begin{array}{llll}61 & 8 & 1 & \text { KTOV }\end{array}$

$\begin{array}{llll}62 & 8 & 2 & \text { USZJNEI }\end{array}$

$\begin{array}{llll}63 & 9 & 1 & \mathrm{IJ}\end{array}$

$\begin{array}{llll}64 & 9 & 2 & \mathrm{UJ}\end{array}$

$\begin{array}{llll}65 & 9 & 1 & \text { KTOV }\end{array}$
Én erre azt mondtam, hogy fanyúvô. Itt van a két csizmája, itt van a szakálla.

D A fanyúvônek nincs szakálla, drágám. (ránéz)

D De van. És te mit mondtál rá, szívem?

Ez egyból vadkan, itt a szeme, füle, orra, agyar.

Ez a füle, itt a szeme, ez meg az agyara. (a másik részekre gondol)

Miért kell minden részletnek belepasszolni? Így van a fej.

RNE De az elóbb te vágtad hozzám, hogy a 2/3-része. (ránéz)

Nem találtam meg benne, amit te mondtál. Tólem lehet fanyúvô, de akkor le van vágva könyökbôl a keze. Na, mi legyen?

Legyen vaddisznó.

Én erre azt mondtam, hogy denevér.

RPO Én is azt mondtam, hogy denevér. Akkor ez egy denevér. Legyen piros és akkor mindenevér. (ránéz)

Szerintem ez egy kikészített bör.

Én is azt mondtam, de olyan, mint a Gyalog kakukkban a farkas, itt van az orra.

Feje, füle, pofa izé.

RPO Erre én nyakékeket mondtam. (ránéz)

Én erre azt mondtam, hogy olyan, mint egy harcos sisak a rómaiaknál. Vagy két indián csaj szemból, itt a toll, arca, teste.

RPO Van ilyen maja nyakék. Én ebbôl nem engedek. (ránéz)

Szerintem ez egy maja nyakék lesz. Ezt a legôszintébben mondom.

Én erre azt mondtam, hogy hôtérképe valami rágcsálónak. Ez itt a gerince.

Én erre azt mondtam, hogy kínai vagy japán harcos. Itt a sisakja, arca, nagy táblákkal van levédve a keze, lába.

KR Azt vértnek hívják, igen. És a kínaiaknak sose volt ilyen harci sisakjuk.

Akkor legyen egy fantáziafilm-szereplō.

Jó, legyen harcos.

Erre azt mondtam, hogy predátor, fogai szeme. Itt meg diskuráló grófnók.

Susmus, én azt mondtam.

Ott vannak a fejek. 


$\begin{array}{llll}66 & 9 & 2 & \text { HEJN } \\ 67 & 9 & 1 & \text { USZJNNEI } \\ 68 & 10 & 2 & \text { IJ } \\ 69 & 10 & 1 & \text { UJ } \\ 70 & 10 & 2 & \text { STOV } \\ 71 & 10 & 1 & \text { UJ }\end{array}$

$\begin{array}{llll}72 & 10 & 2 & \text { SI }\end{array}$

$\begin{array}{llll}73 & 10 & 1 & \text { USZJNEI }\end{array}$
Teljesen.

Akkor konszenzus.

Tulipán.

Nekem katasztrófa.

RPO Nézd meg itt a szára, mindene megvan. (ránéz)

Ja, és baltával kettévágták? Még mindig az enyém áll a legközelebb, én egy nagyon csúnya kollégiumi buli alatt láttam ilyesmiket. Vagy pedig a tárlemez, amit vízfestékkel tettek tisztába, és akkor itt vannak az idegsejtek, látod ezek itt baktériumok. De nem olyan, mint egy tulipán?

De, roncs tulipán, aki egyébként vigyorog, mert itt a két szeme, szája.

Magyarázat: ssz = sorszám, tbl: Rorschach-tábla száma: nem: férfi = 1; nô = 2; jel-1 és jel-2; kód, rövidítve.

Tekintsük át az egyes döntési helyzetekben kialakult hatalmi viszonyokat!

I.: Nô („Nôstény szarvasbogár”)

II.: Férfi („Két törpe összerúg és vérzik a bokájuk”)

III.: Nô független döntés („két nô, kész!”)

IV.: Férfi („vaddisznó”)

V.: („tökéletes megegyezés”, de a férfi humora „mindenre vér” -t üzen)

VI.: Nô („Gyalogkakukkban a farkas”)

VII.: Nô („Maja nyakék”)

VIII.: Férfi (,Japán harcos”)

IX.: Tökéletes összeszövôdés („susmus”)

X.: Nô („Roncs tulipán”)

A döntéseket kézben tartó fél a feleség, a férj olyan helyzetekben kap döntési jogot, amelyek érzelmi természetúek, femininek (II., VIII.), szorongásgerjesztôk (IV).

Ezúttal (a jegyzôkönyv terjedelme miatt is) eltekintünk a 10 tábla mindegyikének végigelemzésétôl, csupán az elsô („kapcsolatreprezentáns”) tábla és az utolsó (X-es), a közös életszínteret és ennek perspektíváját tükrözố kimeneteli üzeneteket világítjuk meg.

Honnan („itt és most” helyzet) merre, hová (jövôkép) halad ez a pár, és milyen esélyeik vannak a párkapcsolati távlatokat illetôen?

A folyamatdinamika produktumaira (az egyes táblák döntô választartalmaira) azért tekintünk rá, hogy a tudateloottes üzeneteiból összefonódó interpretációs hipotézis megalkotásával segítsük elố a párkapcsolat megértését. (Már ehelyütt utalunk azonban arra, hogy a szimbolikus üzenetek desifrírozása elsôsorban a klinikai és terápiás munkaterület számára jelenthet többletértéket. Ezért az alapfokon tájékozódás számára nem „tananyag”, csupán a megértés vezérfonalául szolgálhat.) 
A vizsgálathoz nagy lendülettel kezdtek hozzá (27 interakciós egység az elsô táblán), a bemutatkozási helyzetben (ez az I. tábla felszólító jellege) fontosnak találták, hogy megfelelően „együttmúködjenek”. A hosszú (73 jelölhetô egységet alkotó) alkufolyamatban az elsô - bemutatkozási - helyzeten kívül a közös identitás (III. tábla) és az autoritáshoz, maszkulin eróhöz való viszony (IV. tábla) jelentett még hosszasabb alkufolyamati erôteret. A többi feladategységben (táblán) kevésbé küzdöttek meg a záró megegyezés kialakításáért.

A viszonydimenziók szerinti feltárásban az elsó tábla megoldásának menetében szinte úgy képezôdött le viszonyuk, mint cseppben tükrözôdik a tenger. Szemléljük meg az elsố tábla dominancia dimenziójának páros elrendezódéseit.

\section{Dominancia, I. tábla}

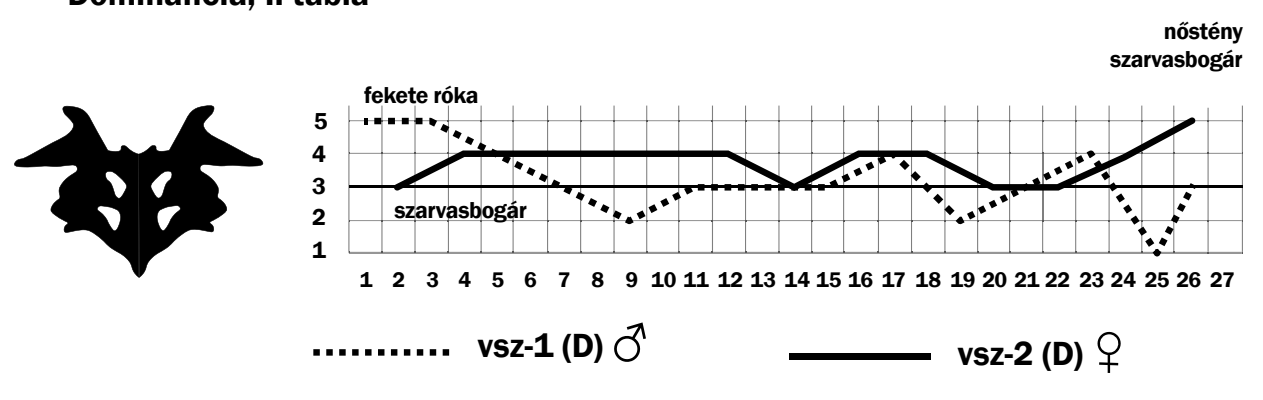

1. ábra. Dominancia, I. tábla

Ádám domináns, indító erôpozíciójából látjuk a „hanyatlási folyamatot”, amelyben önalávetô próbálkozásai (3 ízben) eredménytelenek maradtak. Éva a férfival ellentétben a dominancia térfelén maradt mindvégig, és a férfi rivális próbálkozásait (17. és 23. egység) éppúgy igyekezett vetélkedéseivel leszerelni, mint ahogyan figyelmen kívül hagyta a férfi önalávetô ajánlkozásait is. Indító javaslatát erôszakosan keresztülvitte, a férfi pedig utolsó szó kimondási lehetôségével fogalmazta meg a „nôstény” erôszakot,

érzelmi hullámzás, ambivalencia
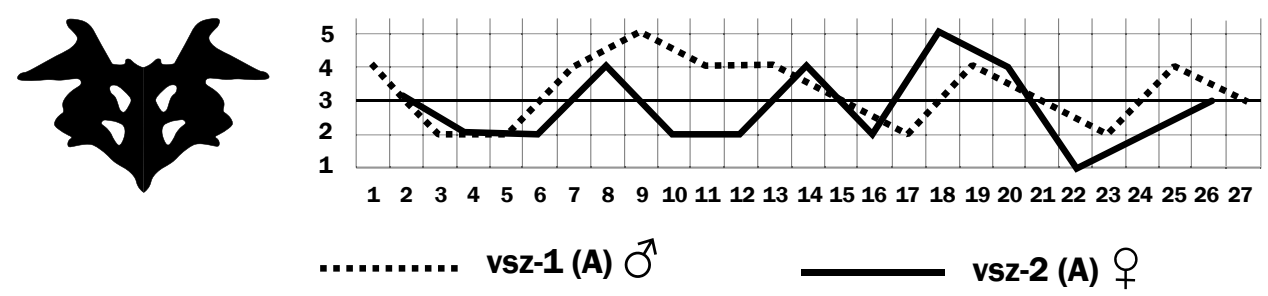

2. ábra. Ádám és Éva intimitásmenete, I. tábla 
alárendelve magát a nôi hatalomnak. Éva erôszakos attitûdje szükségessé teszi az intimitásviszonyok feltárását is.

Amint a fenti, az intimitásdimenziók viszonyát láttató ábra tükrözi, a semleges szinttôl jelentôsen eltérô „fenn-lenn” ingadozást láthatunk mindkettőjüknél. Éva magasabb és mélyebb érzelmi hullámokat él át, de Ádám „mérsékelt hófoka” (4-es értékek!) is képes fellobbanni (9-es interakció), amikor esélyt érez a „gyózelemre”. Éva érzelmi csúcsreakciója (18-as egység) ehhez a mondathoz kötődik: „Akkor találjunk valami harmadikat."

a férfi aktívabb, „küzdốbb”
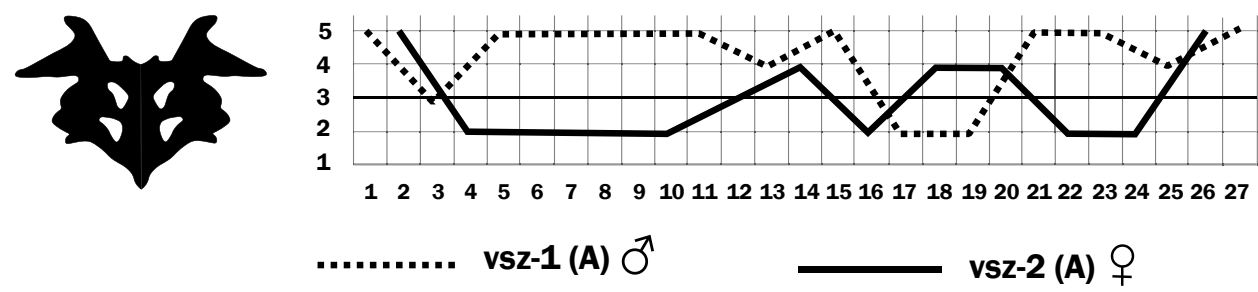

3. ábra. Ádám és Éva aktivitásmenete, I. tábla

Az aktivitásra vonatkozó kölcsönösségi viszonyminta (3. ábra) azt tárja élénk, hogy Ádám az együttmúködésért küzd, a pozitív térfélen marad csaknem végig. Akkor veszít erejéból, amikor Éva felveti számára, hogy „Akkor találjunk valami harmadikat” (17-18-19-es BSU). Éva zuhanórepülésben jut át az akadályozó térfélre a negyedik akcióegységben (ez az ô második válasza!), ettôl kezdve döntôen ebben a szerepében is marad. Ádám sokkal jobban küzd a kapcsolatért, mint saját férfi dominanciájáért. Errôl árulkodik a dominancia vs. aktivitás diagram pár, melyet a 4. ábrán szemléltetünk.
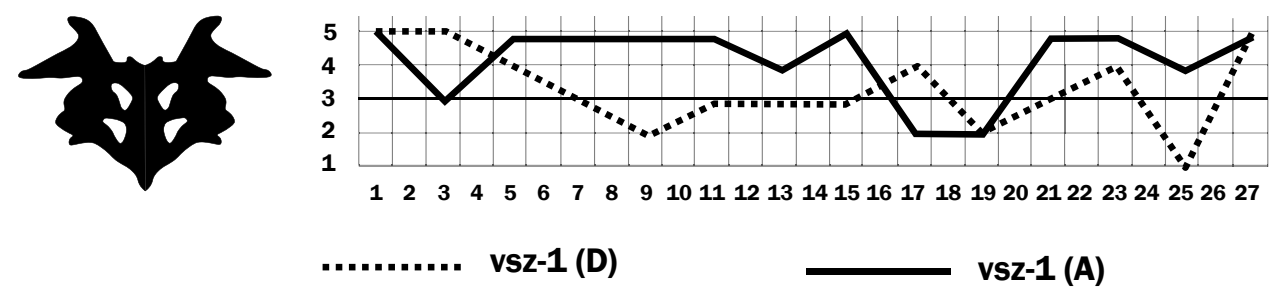

4. ábra. Ádám I. táblán mutatott aktivitása és dominanciája

Éva ezzel szemben túlnyomóan az akadályozó aktivitásban „tevékeny”, a negatív térfélen tartva a feladatmegoldás „elôsegítését”, miközben dominanciája intenzív (lásd 5. ábra). 

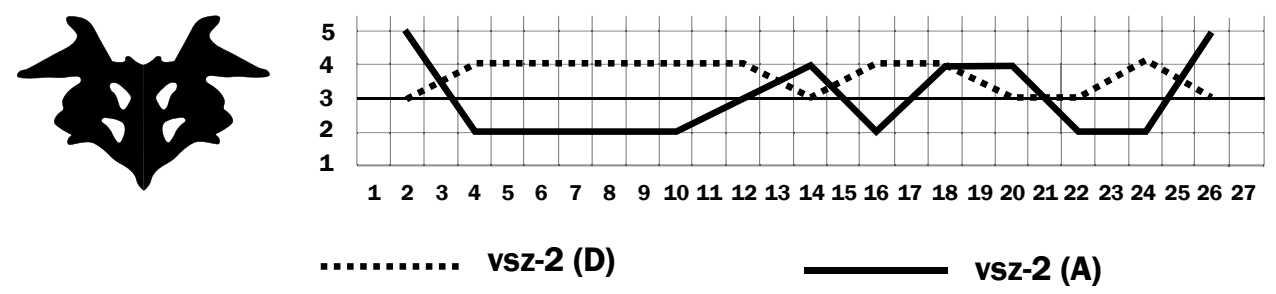

5. ábra. Dominancia (szaggatott) és aktivitás (vonal) viszonya Évánál az I. táblán

A bemutatkozási helyzetkép kedvezôtlen. Együttmúködés helyett Éva egyoldalú és tekintetbevétel nélküli dominanciáját, szeretetlenségét és a közös produktumot gátló aktivitását találjuk jellemzônek. Ádám erôbevetése mindezek ellenére erôteljes. Aktívan küzd a közös produktum létrehozásáért, érzelmileg kevésbé ingadozó, mint párja, noha ambivalenciája kétségtelen.

Ádám nem tud domináns helyzetet elérni, bármit tesz, Éva fölékerekedve, önszempontúan dönt, kényszerúen elfogadtatva vele akaratát. A küzdelemben Ádám alulmarad. A viszonyminták kritikus pontja a 17-18-19-es textusegységhez kötôdik, melynek szövegét érdemes visszaidéznünk:

17. Ádám: Ellenben egy szarvasbogár az pont ilyen (ironikusan): ezt a képet találom meg a határozóban.

18. Éva: Akkor találjunk egy harmadikat.

19. Ádám: Nincs harmadik. Most miért? Harmadik elóbb is eszembe jutott volna, azt mondanám most a róka helyett (ránéz Évára).

Ha a „bemeneti” oldalt, a bemutatkozás jelenét megnéztük, tekintsünk most a kimenetelre is.

Hogyan élnek a közös életükben? (X. tábla) Milyenek a távlati kilátásaik? (záróválasz).

\section{Dominancia, X. tábla}
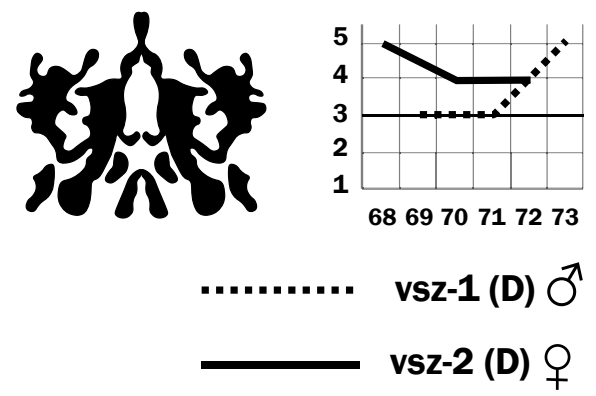

6. ábra. Dominancia X. tábla - Ádám és Éva (Ádámot a szaggatott, Évát az egyenes vonal jelzi) 


\section{Dominancia, X. tábla}
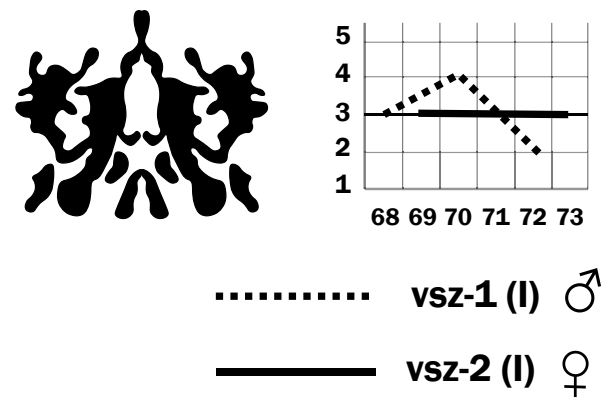

7. ábra. Intimitás X. tábla - Ádám és Éva (Ádámot a szaggatott, Évát az egyenes vonal jelzi)

A dominanciaviszonyok terén mindkettő az egymással vetélkedő, kölcsönösen domináns pozícióban rögzült (6. ábra). A „harcos” térfélen küzdenek. Ádám békés indítása (3 érték) felszökik az 5-ös értékre, így reagál Évára.

Az intimitás dimenziójában Ádámot egyenletes semlegesség jellemzi, míg felesége az érzelmek hullámzásában, ambivalens váltakozásában az elutasító, negatív érzelmi térfél felé tendál (lásd 7. ábra).

Aktivitásuk, a „közös ügy” megoldására vonatkozó erejük még elengedô volna ahhoz, hogy a megoldást elôsegító lépéseket tegyenek, de Éva ereje a letörés felé, aktivitása a semlegesség irányába halad. A férfi aktivitása még magas fokú, töretlen, de érzelmileg már semleges (8. ábra).

A kapcsolati folyamat elejére és végére rátekintve megállapíthatjuk, hogy kedvezôtlen kapcsolati bemutatkozást, érzelmileg Éva oldaláról ambivalenciát és hôfokcsökkenést, dominanciaốrzô, erôszakos és tekintetbevétel nélküli viszonyulást figyelhettünk meg. Ádám „küzdelmére” is ráláthattunk, melyet felesége megnyeréséért, együttmúködésének eléréséért tett, hiábavalóan. Éva a döntést saját javaslata alapján erôszakolta ki, mire Ádám a nôstény (szarvasbogár) jelzôvel megtoldott „kombináció” árán

\section{Aktivitás, X. tábla}
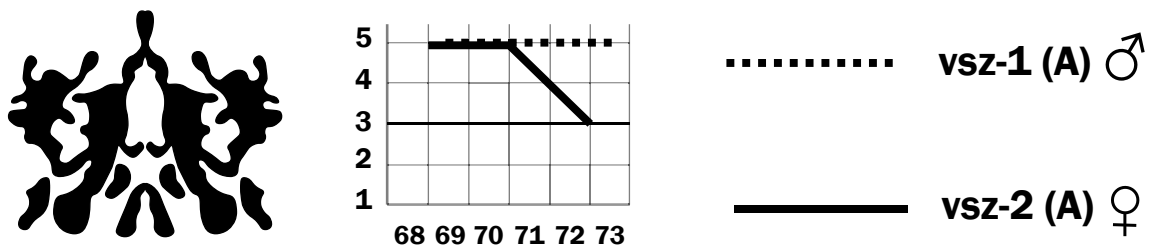

8. ábra. Aktivitás X. tábla - Ádám és Éva (Ádámot a szaggatott, Évát az egyenes vonal jelzi) 
maradt benn a kikényszerített döntésben. Az indító érzelmi erôbevetésben Ádám felülmúlta feleségét, aki inkább a negatív érzelmek megnyilvánulásában jeleskedett.

A Közös Rorschach alkufolyamat végére a kialakuló kép azt láttatja, hogy az életszíntéren és a jövố felé kilépésben (X. tábla) az erejét vesztett érzelmek (Âdám), az ambivalenciaérzések (Éva), a dominanciapozícióért versengés, Ádám aktivitásának (immár érzelmektốl nem befolyásolt) épsége, viszont Éva indítékerôinek megcsappanása figyelhetố meg.

Ehelyütt akár be is fejezhetnénk elemzésünket. Kössük azonban össze a kezdetet a véggel oly módon, hogy a szimbolikus üzenettartalmakat desifrírozzuk. Valamennyi Rorschach-táblán megvizsgáljuk a döntéstartalmat. Jelentés szempontjából az egyéni Rorschach-vizsgálat „tartalom” (III. oszlop) jeleinek a teszt használatában érvényes jelentéseit használtuk fel (Mérei, 2002).

Értelmezési munkánknak ez a része elsôsorban a pszichoterápia (egyéni, pár, család) módszertani területen beavatódó (tanuló) vagy terápiás munkát végzô szakemberek számára jelenthet szakmai többletet, hiszen a terápiás helyzetben is ezzel a „harmadik füllel” (Luban-Plozza és Dickhaut, 1998) hallgatjuk és desifrírozzuk a kliens/ páciens metaforikus vagy többjelentésú közléseit.

A Rorschach-üzenettartalmak „csatornáján át” kiáradó, nagy lelki nyomású üzenetek felôl közelítve, az indítás vitája a "fekete róka” (Ádám) és a „szarvasbogár” (Éva) között zajlik. A párbeszéd „kiszólásai” („Zsákutcába fogunk így jutni”, „Akkor találjunk egy harmadikat”, „Ha megkötöd magad, akkor semmi értelme végigcsinálni”) a kapcsolatra is vonatkoztathatók, hiszen itt önmagukat mutatják be. Olyannyira, hogy a férfi záró összegzése (,Szerintem egy nôsstény szarvasbogár. És most volt a 10. évfordulónk”) ezt kétségtelenné teszi. A tízéves házasságra utalás egyértelmú.

Az érzelmi helyzet szempontjából így szól az elfogadott üzenet (II. tábla): „két törpe összerúg, és vérzik a bokájuk”. A törpék (= soha felnôni nem tudó lények) megsebzik egymást a bokájukon („megütheted a bokádat!” = veszélybe kerülsz). A jelentés azt sugallja: a házasfelek érzelmi kapcsolata veszélyben van. Érzelmileg nem „nôttek fel”. Ez az alaphelyzet. (Csakhogy a párkapcsolat nem homokozóban folytatott játék!)

A III. (identitás) táblán a férfi-nô páros helyett (mindenáron) két nô szerepel, ami a férfierố hiányát üzeni ebben a kapcsolatban. Itt Éva az úr.

Az autoritás (maszkulinitás) hívóhelyzetében (IV.) a férfi ragaszkodik a „vadkan” tartalomhoz (= erố és vadság képviseli számára a férfiasságot). Éva ezt tiszteletben tudja tartani, de vad „disznóra” degradálja a férfierôt.

Az V. (realitás) táblán látszatra tökéletes összhang csendül ki, az élet realisztikus dolgaiban nincs köztük ellentét. A férfi az egyetértést humorával emeli meg (denevér-denevér-mindene vér), benne („cry for help”) szól a sebzettségrőll („min[dene]-vér”).

A szexualitás (VI.) hívóhelyzetében Éva „a szexuális helyzetet” „Gyalog kakukk farkasának” degradációjával teszi nevetségessé. Uralja a helyzetet, „kasztrálja” férje szexuális nembeliségét.

A nốiség (VII.) hívótábláján a „maja nyakék” tartalom (= klasszikusan értékes kincs) nem képezheti vita tárgyát. Éva azt szögezi le: „Én ebbôl nem engedek.” Ádám behódolva erôsíti meg: (ezt én is) „a legốszintébben mondom”. Ádám „lovagszerep- 
ben” szolgálja Évát, aki ezt megkívánja. A szexualitásban azonban Éva annullálja, kvázi kasztrálja párját.

A gyengéd kötôdés helyzetében (VIII.) az agresszió helyettesíti a gyengédséget a férfi számára (= ,japán harcos”), ezt a feleség helyesli. Ha nincs pozitív stroke, van helyette negatív (ütés). Kettejük „harcában” a szamuráj mindent elvisel, Ádám hôs.

A teljesítmény (IX.) területén a „predátor” rémképétôl a „diskuráló grófnôiig” halad az egyezség, utóbbiban konszenzusra jutnak. Diskuráló grófnók (ráérnek csevegni, mert „urak”). A közös vágyott helyzet a „suskus”. Valóban ezt múvelik. Játszmájuk tökéletes.

Végül a X. táblán a tulipán (= nôiség) és a katasztrófa (= a férfi megajánlott üzenete) felôl destruktív lépéseken át jutnak el a „roncs tulipánig” (melynek „szeme van és vigyorog").

A kapcsolat perspektívájában ez a záradék nem ad pozitív esélyt a viszony hosszú távú fennmaradásának. A nô X. táblán (18-as egységben) nyújtott egyetlen (kiugróan) pozitív érzelemhez kötött üzenetét szükséges visszaidéznünk: „Akkor találjunk egy harmadikat!” Mivel ez a javaslat az indító helyzetben is elhangzott már a nô szájából (I. 18. „Akkor találjunk valami harmadikat”), a kapcsolat kinyitása bejósolható jövô. Aligha remélhetjük, ugyanis, hogy ez a harmadik egy közös gyermek lenne. A férfi érzelmileg kötöttebb (I. 19. „Nincs harmadik. Most miért? Harmadik előbb is eszembe juthatott volna, azt mondanám most a róka helyett”). Számára a harcos csatározás, a küzdelem, az agresszió az érzelmek pótléka (VIII. „gyengédség” táblán ,japán harcos”). Azzal pedig a feleség is egyetért, hogy az agresszió, az egymással csatározás gyengédségpótlék, mivel ô kifejezetten ezt múveli férjével. A „suskus” egymással összhangban a (tudattalan) összejátszást tárja fel elốttünk.

Az összkép ebben a viszonyban a harcos, „fallikus nô” és ôt kiszolgáló párja közti „fallikus kollúzió” dinamikáját (Willi, 1978) tükrözi azzal az eséllyel, hogy Éva „férfiatlanítási buzgalmában” a kapcsolat a „harmadik” felé kinyitással zátonyra fut.

A pár kollúziómentesítése (párterápiája) kínálja e helyzet egyedüli reményteli megoldását. Ezt azonban a kollúzív viszonyban élố párnak csak akkor ajánlhatjuk, ha ôk kérik segítségünket.

\section{MÁSODIK ESET: „MARADJ(UNK) KISLÁNY(OK)”}

\section{Anorexia nervosában szenvedô lány és anyja kapcsolata}

Második esetelemzésünket a klinikum világából választottuk. Ebben indokolt ugyanis a tartalmi analízis elvégzése is, így teljes processzometriai feldolgozást mutathatunk be.

Egy 15 éves, anorexia nervosában szenvedô lány és 42 éves édesanyja kapcsolatának mélyére tekintünk. A felszín (viselkedési manifesztáció) felől haladunk a kifejezési folyosón a projektált tartalmak, mint szimbolikus, „virágnyelven” küldött üzenetek felé. Ebben a Mérei-féle felszólító jelleg koncepciót követjük (Mérei, 1947). 
A lány második gyermek, nôvére sikeresen végzi az egyetemet. Édesapja foglalkozása (értelmiségi diplomás) és nôvére választott szakmája azonos. Évi (nevezzük ôt így) „tizenegy évesen veszítette el az étvágyát”. Gimnáziumba kerülve nagy nehézségekkel találta magát szemben. Baráti körében megrendült a bizalma, legjobb barátnôje szerelembe bonyolódott. Ez az érzés Évit még nem érintette meg. Csúnyának érezte magát, a fiúktól tartózkodott.

Édesanyja mindig fokozottan törôdött vele, ô volt a legkisebb, gyengébb gyermek. Az utóbbi idôben már idegesítette anyja gyámkodása, de mégis úgy érezte, az ô segítségére számíthat.

A koplalási szokás folyamatosan alakult ki, elôször csak nem reggelizett, idegesen ment az iskolába. Aztán az ebédet hagyta ki, mert mindig rohanni kellett valahova (különórák, sport). Ha tornázott, úgy érezte, más lelkiállapotba került. Tapasztalta, hogy a testsúlya csökken, ennek egyre jobban örült. Osztálytársától hallotta, hogy lehet veszélytelenül bezabálni, csak meg kell hánytatnia magát utána. Anyja egy ízben az esti hánytatását észrevette, kétségbeesett tốle. Mindig szerette etetni a lányát, akinek rapszodikus evési szokásai aggasztották.

Hosszas huzavona után megegyeztek, hogy orvoshoz fordulnak. A diagnosztizált anorexia (súlyos fogyás, menses kimaradása, szôrnövés-fokozódás, éhségödéma a lábon, önhánytatás, több mint egy éve fennálló, rosszabbodó állapot, fokozott testi igénybevételek [tornázás] stb.), a kórisme nyomán megkezdődött a kezelés, amelyben a pszichoterápia is helyt kapott. Az anya készségessége felvetette a családterápia lehetôségét is. A KRV vizsgálatban szívesen vettek részt. Az édesanya a lányát engedte elốre, miután ô leült, az üresen maradt széken foglalt helyet.

A következôkben a (felek írásban rögzített engedélyével) magnetofonra felvett, már lejelölt jegyzőkönyvet mutatjuk be. A kiemeléssel jelöljük meg az értelmezett üzeneteket. A VII-es táblát (mely az anyaság, nôi identitás, a saját anyához való viszony három réteget tárja fel) felszólító jellege és az informatív dialógusból feltáruló üzenetek miatt teljes egészében kiemeltük, hogy a mélyebb jelentésrétegekre is rávilágíthassunk. Ezúton köszönöm a processzometria pszichometriai tökéletesítésén fáradozó Csákvári Zsófiának, Kiss Dalmának és Vetier Annának a jelölés munkájának (egymástól független) elvégzését, majd az interrater reliabilitás ellenôrzését. Ez a jegyzôkönyv is részét képezi a jelölési megbízhatóságot tesztelố vizsgálatnak (Bagdy, Csákvári, Kiss, Vetier és Vargha, 2006). 


\section{A Közös Rorschach-jegyzókönyv jelölése}

2. táblázat. Anya-lánya KRV-jegyzőkönyve

$\begin{array}{llll}\text { SSz } & \text { tbl } & \text { N } & \text { jel-1 } \\ & & & \\ 1 & 1 & 2 & \text { IK } \\ 2 & 1 & 1 & \text { UJ } \\ 3 & 1 & 2 & \text { HEJN } \\ 4 & 1 & 1 & \text { USZJNEI } \\ 5 & 2 & 2 & \text { IK } \\ 6 & 2 & 1 & \text { FV } \\ 7 & 2 & 2 & \text { FV } \\ 8 & 2 & 1 & \text { KV } \\ 9 & 2 & 2 & \text { UJ } \\ 10 & 2 & 1 & \text { UJ } \\ 11 & 2 & 2 & \text { HEJN } \\ 12 & 2 & 1 & \text { KV } \\ 13 & 2 & 2 & \text { MTOV } \\ 14 & 2 & 1 & \text { MTOV } \\ & & & \\ 15 & 2 & 2 & \text { USZTNNEI } \\ 16 & 3 & 2 & \text { IJ } \\ 17 & 3 & 1 & \text { MTOV } \\ 18 & 3 & 2 & \text { HEJN } \\ 19 & 3 & 1 & \text { KTOV } \\ 20 & 3 & 2 & \text { KTOV } \\ & & & \\ 21 & 3 & 1 & \text { SI } \\ 22 & 3 & 2 & \text { USZJNEI } \\ 23 & 4 & 1 & \text { IJN } \\ 24 & 4 & 2 & \text { UJ } \\ 25 & 4 & 1 & \text { MTOV } \\ & & & \\ 26 & 4 & 2 & \text { USZJNNEI } \\ 27 & 5 & 1 & \text { ITJ } \\ 28 & 5 & 2 & \text { MTOV } \\ 29 & 5 & 1 & \text { USZJNEI } \\ 30 & 6 & 2 & \text { IK } \\ 31 & 6 & 1 & \text { BIZT } \\ 32 & 6 & 2 & \text { UJ } \\ 33 & 6 & 1 & \text { ELL } \\ 34 & 6 & 2 & \text { STOV } \\ 35 & 6 & 1 & \text { USZJNNEI } \\ 36 & 7 & 1 & \text { ITJ }\end{array}$

\section{jel-2 szöveg}

$\mathrm{Hm}$ ?

Nekem lepkéhez hasonlít.

Jó, elfogadom.

Szárnyai is vannak.

F Mondd, mi ez?

Mire tippelsz? Valami csúfság. Hogyan kell nézni?

Ahogy tetszik.

Egyik rondább, mint a másik.

Mintha két kéz lenne és valamit fogna.

Igen? A véresek az ujjak? Nekem bivalyra hasonlít.

Meglehet.

Nem tudom, mi a piros.

Nem is bivaly, két medve.

MK Igen, szinkronban. Lehet, felfalnak valamit, és a véres dolgok maradnak ott, nem?

Ühm.

Szerintem két ember, két nô. Itt. (mutatja)

Igen két ember és valamit csinálnak.

Igen.

MK Nem mosnak, hanem korongoznak, nem?

Igen. Mik ezek a vérfoltok? Lehet, hogy nézi óket valaki, csak az nem látszik.

Két nô, csinálnak valamit.

Ellenségeskednek.

Valami hasonszôrú volt már.

Szőrös állat.

Ez az! Szôrös állat vagy bogár. Valami ronda szőrös állat, nem?

Igen.

Nekem ez denevér.

Tényleg, itt vannak a lábai.

Biztos denevér.

Mennyi ilyen van még? Na, ez mi lehet?

Legyen ötleted, majd én elfogadom.

Tengeri élôlény, tengeri csillag.

A csillagnak nem ilyen alakja van.

Tengeri herkentyú.

Jó! Ez jó.

Feltrancsírozott nyuszi. 


$\begin{array}{llll}37 & 7 & 2 & \text { ELL } \\ 38 & 7 & 1 & \text { STOV } \\ 39 & 7 & 2 & \text { MTOV } \\ 40 & 7 & 2 & \text { STOV } \\ 41 & 7 & 1 & \text { IG } \\ 42 & 7 & 2 & \text { DOK } \\ & & & \\ 43 & 7 & 1 & \text { USZJNNEI } \\ 44 & 8 & 1 & \text { IK } \\ 45 & 8 & 2 & \text { ELL } \\ 46 & 8 & 1 & \text { STOV } \\ 47 & 8 & 2 & \text { FV } \\ 48 & 8 & 1 & \text { IG } \\ 49 & 8 & 2 & \text { USZJNNEI } \\ 50 & 9 & 1 & \text { IK } \\ 51 & 9 & 2 & \text { FV } \\ 52 & 9 & 1 & \text { FV } \\ 53 & 9 & 2 & \text { UJ } \\ 54 & 9 & 1 & \text { HEJN } \\ 55 & 9 & 2 & \text { KTOV } \\ 56 & 9 & 1 & \text { HEJN } \\ 57 & 9 & 2 & \text { DOK } \\ 58 & 9 & 1 & \text { USZJNNEI } \\ 59 & 10 & 1 & \text { ITJ } \\ 60 & 10 & 2 & \text { UJ } \\ 61 & 10 & 1 & \text { SI } \\ 52 & 10 & 2 & \text { STOV } \\ 63 & 10 & 1 & \text { MTOV } \\ 64 & 10 & 2 & \text { HEJN } \\ 65 & 10 & 1 & \text { TK } \\ 66 & 10 & 2 & \text { ELL } \\ 67 & 10 & 1 & \text { OSSZ } \\ 68 & 10 & 2 & \text { HEJN } \\ 69 & 10 & 1 & \text { KTOV } \\ 70 & 10 & 2 & \text { HEJN } \\ 71 & 10 & 1 & \text { KTOV } \\ 72 & 10 & 2 & \text { USZJNNEI }\end{array}$

De nem egy, hanem négy.

Így feltrancsírozva és szétcincálva.

Phú! De akkor is kettô.

Így a lába, a teste.

Szegény. Nincs jobb ötletem.

Szegény kis feltrancsírozott nyuszi. Nincs jobb ötletem, nem?

Jó.

Itt szép színes valami! Milyen állat van rózsaszín?

A rózsaszín párduc, de ez nem olyan jellegú.

Van négy lába, de mire mászik?

Elég egy részét elfogadni, de a többit passzoljuk.

Biztos a két állat.

Jó.

Mennyi pacnit kapunk! Van ötleted?

Hát nem látom.

Így sem jobb!

Tudod mit? Lámpa, mécses lángja.

Ühm, nem rossz ötlet.

Középen ég ez a dísz.

Nem rossz ötlet.

Elfogadod?

El, ügyes vagy.

Jaj, de szép! Ott egy vár!

Polip.

Ott egy vár.

Rákok.

MK Ez hínárféle, nem?

Ühm.

Mi ez a kék? Hidacska?

Nem jó.

MK Akkor az egész nagy víz és közte sziget, nem?

Igen.

Szigeten a vár, és sok-sok állat, polip, pók.

Ühm.

Halacska.

Ühm.

Magyarázat: ssz = sorszám, tbl: Rorschach-tábla száma: nem: anya = 1; lány = 2; jel-1 és jel-2; kód, rövidítve. 


\section{Elemzési folyamat}

Vizsgáljuk meg elôször a dominanciaviszonyokat!
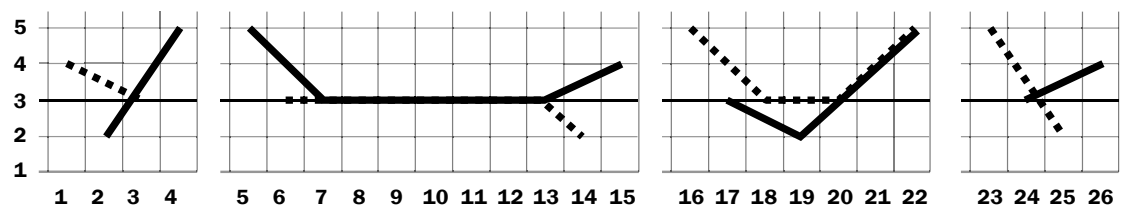

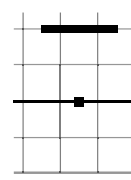

272829

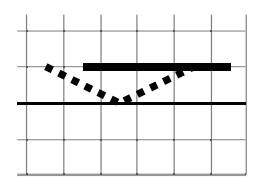

303132333435

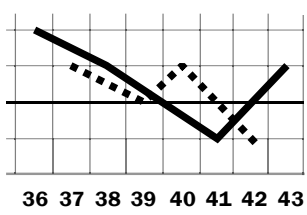

$\begin{array}{llllllll}36 & 37 & 38 & 39 & 40 & 41 & 42 & 43\end{array}$

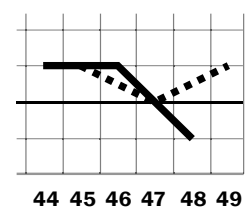

$44454647 \quad 4849$

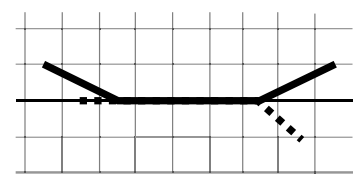

505152535455565758

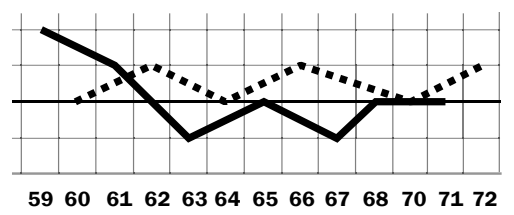

anya

\section{lánya}

9. ábra. Dominanciaviszony folyamata az I-X-es táblán (az anya jelzése az egyenes vonal, a lányáé a szaggatott vonal, a továbbiakban a két személy jelzése állandó)

A semleges (3-as) feletti zónába kerülő értékek az önérvényesítési törekvés jelzései. Többségében mindvégig ezek uralják a helyzetet, de az anya hétszer kísérli meg az (enyhe fokú) alárendelôdést (II., III., IV., VI., VII., X. tábla). Többnyire azonban innen visszatér a „küzdelmi” térbe (III., IV., VII., X. táblákon). A dominancia térfélen is hét esetben kerül lánya fölé, erôteljesebb lépésekkel, mint a lánya. A „fölé-alá rendelốdô lépések tánca” az anyát jellemzi, mintha „körültáncolná” lányát, azonban végül mégsem enged. Küzdelem zajlik tehát, az anya halvány önmegadó próbálkozásaiból visszatáncol a dominanciába, de az alárendelôdés felmutatási készségével azt láttatja, hogy ô kompromisszumkész és segítô. Ha a szöveget (Rorschach-jegyzôkönyvet) olvassuk, ez a benyomás létre is jöhet bennünk. 

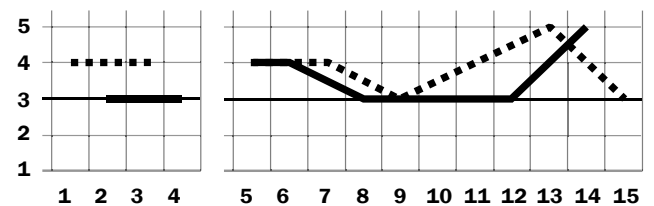

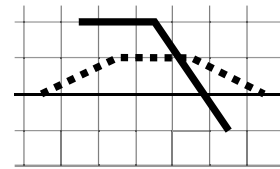

16171819202122

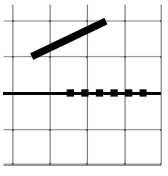

23242526

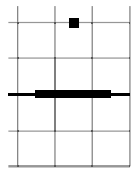

272829

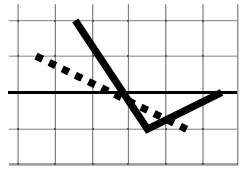

303132333435

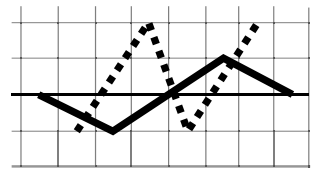

$36 \quad 373839404142 \quad 43$

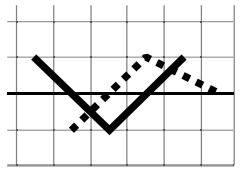

$44454647 \quad 4849$

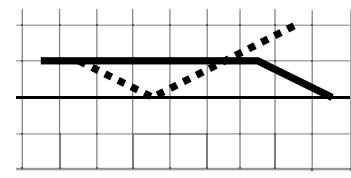

505152535455565758

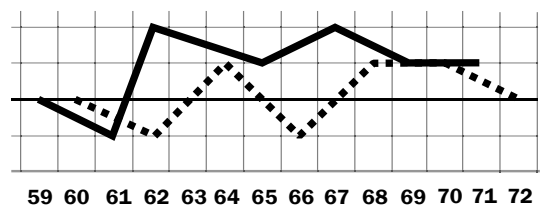

anya

lánya

10. ábra. Intimitás az I-X-es táblákon

Az intimitásviszony (lásd 10. ábra) kifejezésére rátekintve az elsố két helyzetben (I-II. tábla) a pozitív érzelmek térfelén folyik az üzenetváltás. A dominancia és intimitás pozitív kapcsolódása (magas szintje) a szimmetrikus együttmúködố kapcsolat jellemzôje. Az elsô (bemutatkozási) helyzetben ezt láthatjuk, amely a második lépésben komplementer együttmúködésbe vált át az anya elmozdulásának köszönhetôen. Itt alárendelốdik. A harmadik táblán azonban az anya negatív érzelmi térfélre lendül át (ennek a tartalmakkal való összefüggését érdemes majd szemügyre vennünk), a VI. táblától kezdve pedig kettejük érzelmi fenn-lenn, ambivalens viszonya „csatázik egymással”. Fokozatát illetốen „enyhe” negatív kibillenéseket láthatunk, a szélsô negatív indulat hiányzik. Csak a IV., V. és IX. tábla „békés”, az anya „enged” (dominanciaérték: 2) és pozitív érzelmeket ad (érzelem: 4 és 5). Az „autoritás” felszólító ingerhelyzetében enged, a „realitástudatot” tükröző V. táblán azonban éppen fordítva, az anya dominál (5 kétszer), míg Évi a semleges pozícióból igen sok érzelmet ad (1:5). A „realitásban én vagyok az úr, nem a szeretet számít" - üzeni ez a viszonyulás az anya részérôl. Évi viszont ekkor is tud a számára érzelmet adni. Ahol pedig a „teljesítmény” hívóhelyzete jelenik meg (a IX. tábla), ott ismét az anyai dominanciával vezetett (illeszkedô, komplementer), együttmúködô (érzelem+ és aktivitás+) viszonyminta jelenik meg. „Tudok anyai vezetéssel teljesítményt produkálni” - üzeni ez a viszonyminta. 

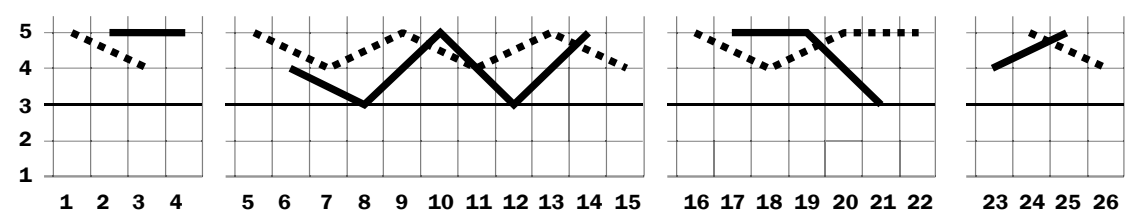

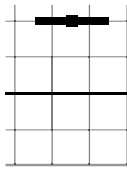

272829

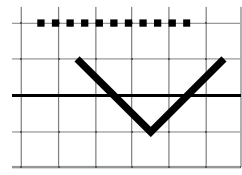

303132333435

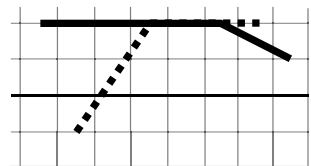

3637383940414243

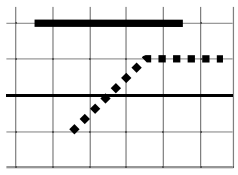

444546474849

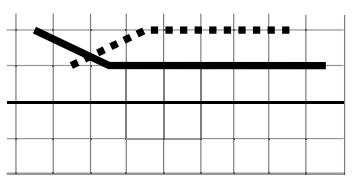

505152535455565758

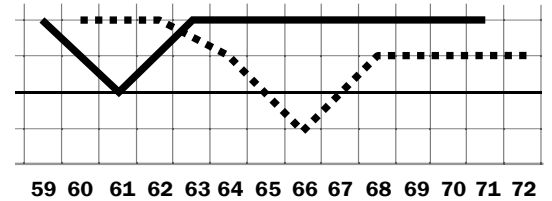

[..... lánya

anya

11. ábra. Aktivitás az I-X-es táblákon

Az aktivitás minôsége is fontos összetevôje a „hatalom vs. érzelem” viszonynak. A közös válaszra törekvés elsố öt feladathelyzetében (I-V. tábla - vagyis az elsố felében) a megoldásra törekvô, azt elôsegítő buzgalom figyelhetô meg, Évi magasabb „hôfokon”, az anya nagyobb ingadozásokkal aktív. Amikor azonban a VI. (szexualitással összefüggô) felszólítás megjelenik és az anya átlendül akadályozó akcióba, Évi „beindul”, és egy kivétellel (IX., közös munka tábla) minden új döntési helyzetben akadályozó interakcióval áll elô (VII., VIII., IX. táblákon).

\section{Elemzés táblánként, „felszólitó jellegek összefüggésében”}

Ha a diagramokról leolvasható, a helyzetben formálódó viszonyminták szövôdésének útját a kibontakozó (tartalmi) üzenetekkel egybevetve nyomon kísérjük, megállapíthatjuk, hogy a bemutatkozási helyzet (I. tábla) „felhôtlen” arculata a szimmetrikus-együttmúködô, közös aktivitásra törekvố állapotot tárja elénk (dominancia +, aktivitás + , intimitás + térfélen van, kölcsönösen!). Az érzelmi érettségi szintre kérdezô második lépésben (II. tábla) Évi intenzív aktivitással (aktivitás: 5,4), „harcos önérvényesítéssel” (dominancia: 5,4) magas érzelmi hôfokon (intimitás: 4,5) vetélkedik anyjával, aki viszont kevesebb érzelmet, kevesebb (és szélsôségesen változó) aktivitást, semleges pozíciót, majd „behódolást” mutat (dependencia: 2 pont). Lányához, annak javaslatához kapcsolódik, annak ötletét „tölti fel” fenyegetô tartalommal („véres ujjak"). (Az anya behívja a helyzetbe a félelmet.) Kapcsolatdinamikai szempontból a III. 

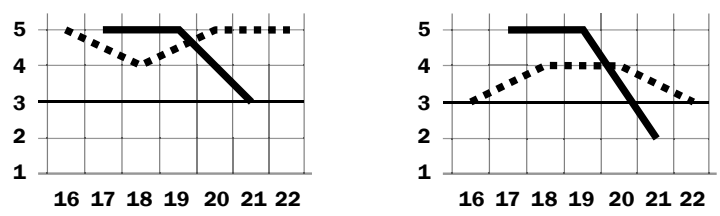

anya

\section{lánya}

12. ábra. A III-as tábla aktivitási (bal oldali ábra) és intimitási (jobb oldali ábra) diagramjai

(közös identitás) tábla a lány „gyôzelmét” tükrözi anyja felett. Magas aktivitási erôvel, Évi részérôl azonban anyjától eltérôen kevesebb kimutatott érzelemmel vesz részt az alkuban, melyet eldönt Évi ötlete („két ember, két nő, csinálnak valamit”), és fejlődik végül olyan záradékká, hogy (ezek) „ellenségeskednek”. Már itt észrevehetjük, hogy a viselkedés aktivitásfokozódása és az együttmúködésben (viselkedésben) megjelenô érzelem csökkenése jelezhet valamit. Az alkuba került tartalom adja meg ehhez a kulcsot: „ellenségeskednek”. Az indulat nincs már fenn (a viselkedési szinten), kifutott a kínálkozó „harmadikra”, a projekciós mezôre. A lány kimondta, hogy a „két nô” (anya és lánya) ellenségeskednek. A közös projekciós mezô átmeneti tere „hordozza” és mutatja fel a rejtett ellenségességet.

Az autoritás és realitás (IV. és V.) hívótábláján az interakciós mintázat azt jelzi, hogy a tekintélyi helyzetrôl, autoritásszereprôl az anya kész lemondani, „gyengíti pozícióját”, a projekciós mezóben pedig egyetértenek az autoritás elutasításával és a tôle való félelemmel („ronda, szôrös állat”). Figyelembe véve, hogy ez a kép az „apareprezentáns", a férfiszimbólum, az üzenet mindkettejük esetében ennek elutasítását és félelmüket fejezi ki. A realitás színterén (V. tábla) az anya egyértelmú irányító szerepében egyeznek meg. A VI-os mezô (szexualitás) belépése azonban rányit az anya paradox kommunikációs lépéskészségére, a feltétlen elfogadás látszata mögötti meghatározó szerepre: „legyen ötleted”, „elfogadom”. Ennek során azonban az ígérettel ellentétes viselkedés túnik fel. Amikor Évi eleget tesz a felszólításnak, anyja azonnal elutasítja az ötletét. Hiába dominál(na) a lány, a valódi (rejtett) karmester az anya.
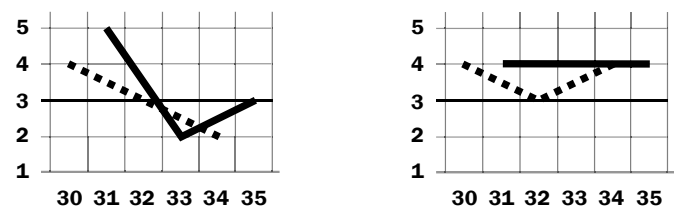

\section{anya}

lánya

13. ábra. Intimitás (bal oldal) és dominancia (jobb oldal) diagramjai, VI-os tábla 
A szexualitásban az ügy devalválására bírja rá lányát („a tengeri csillagból így lesz tengeri herkentyú”). Az üzenet így szól(hat): „ez semmi, nincs jelentôsége”. Megtetézi ezt a helyzetet az anya magas érzelmi hôfoka is, kölcsönös ambivalenciával (13. ábra). A viszonyminta üzenete pedig az: „Úgy irányítok, hogy azt érezd, te vezetsz.”

Az itt felszínre kerülő dinamikai jelenség egyrészt a double bind („mondd” - „elfogadom" - majd mégis cáfolja a mondottakat. Eleget tenni tehát nem lehet.). Másrészt a kerülőutas hatalomszerzés (kontrollmegragadás) metakomplementer viszony jelenségére nyithatunk rá, amely ambivalens érzelmek talaján születik (13. ábra). Idézzük vissza a dialógust:

Lány: Mennyi ilyen van még? Na, ez mi lehet?

Anya: Legyen ötleted, majd én elfogadom.

Lány: Tengeri éloólény, tengeri csillag.

Anya: A tengeri csillagnak nem ilyen alakja van.

Lány: Tengeri herkentyú.

Anya: Jó. Ez így jó.

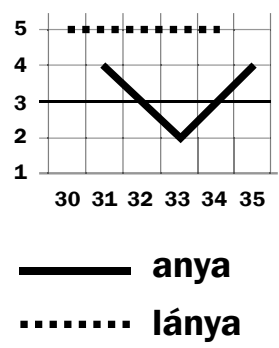

14. ábra. Aktivitás diagram, VI-os tábla

Az anya „dolgoztatja” a lányát, ezt az aktivitásdiagram is szemlélteti. Megjegyezzük, hogy ahol az ambivalencia a viselkedésben feltûnik, ott keresnünk kell a „szellôzési utat”, merre, hogyan jut kifejezésre a - többnyire lehasadó, elhárításra kerülô - negatív rész.

A VII. tábla az anya-lány viszony szempontjából kritikus. Ez a felszólító ingerhelyzete a nôiségnek, anyaságnak, anyához való viszonynak. A tábla nagy kiterjedésú fehér területe pedig beindíthatja az agresszív lelki tartalmakat.
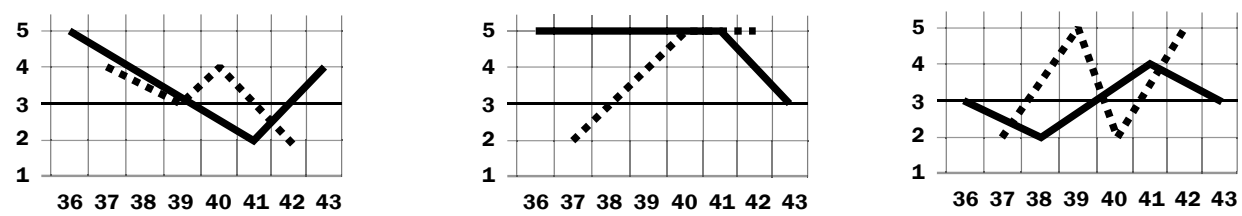

\section{anya}

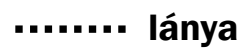

15. ábra. Dominancia (bal oldal), aktivitás (középsô), intimitás (jobb oldal), VII. tábla 
Erôviszonyok szempontjából esetünkben a kapcsolat kulcsüzenete tükrözôdik ezen a táblán. Amint a viszonyminták alakulásán láthatjuk, ez a „legdinamikusabb” tábla.

Az anya-lánya vetélkedésben ezúttal a lány is önalávetô lépéskínálatokat tesz, az anya is, a helyzetet az anya dominálja. Az intimitás-„libikóka” is erôteljes, de a lány több érzelmi töltést ad bele a helyzetbe, mint az anyja. Az aktivitásban a támogató, feladatmegoldásra törekvố szint erôteljes, a lány ellentétes lépése (I. diagram mélypontja) hatástalan. Ilyen erôviszonyok közepette olyan egyezkedést követhetünk, amelynek tétje a tartalmak szimbolikus, „fecsegó nyelvén” az „egy-kettő vagy négy sebzett nyuszi”. Nézzük a dialógust: mirôl szól az üzenetváltás szimbolikus nyelven?

3. táblázat. Anya lánya közötti dialógus és látens jelentése

\section{Manifeszt üzenet}

Anya: feltrancsírozott nyuszi

Lány: de nem egy, hanem négy

Anya: így feltrancsírozva és szétcincálva

Lány: pfúj, de akkor is kettő

\section{Látens tartalom}

Az anya számára egyrôl van szó. (Nyuszi = kislány) Ez a kislány sebzett. A lány tagadja az egységet. „A mi családunk négytagú!"

Az anya üzenete: „sebzett kislány(ok) vagy(unk)”. Mi, egységben, „szét”-szedve. A sebzettség számít, meg az egység. A lány hangsúlyozza az önállóságot, különállást. Két kislány, (nô?) akikrôl szó van.

Az anya szimbiotikus egységbe (ketten egy) képzeli (érzi) kettejüket, félelemteli lényként. A lány ki akar szabadulni a szimbiózisból (de nem sikerül). Egyik sem felnôtt. Az anyai minta egy nôiségétôl, ebben sebződéstôl rettegó, gyermeklelkú nô, aki identitásában gyermek maradt.

A lány már a III. táblán „elmondta” (rejtett) ellenséges viszonyukat, az ambivalencia negatív része tehát az önálló identitásért való - sikertelen - küzdelemben újragerjed.

Mivel ôrzi az anya a szimbiózist? Érzelmi tápjával, amely az „érzelmeket idézô” (VIII.) táblán az ambivalenciáról „fecseg”, ebben viszont lányával szinkron mozgás vehetô észre. Az érzelem elárasztó bôsége az „életmező” (életszíntér) X. tábláján mutatkozik meg kifejezetten, az anya valójában együtt mozog lánya ambivalenciájával.

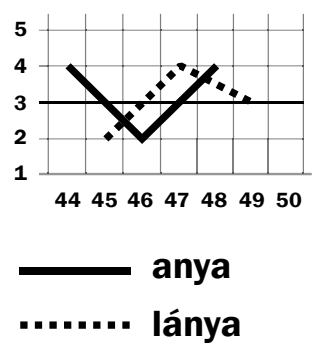

16. ábra. A VIII-as tábla intimitásdimenziója 


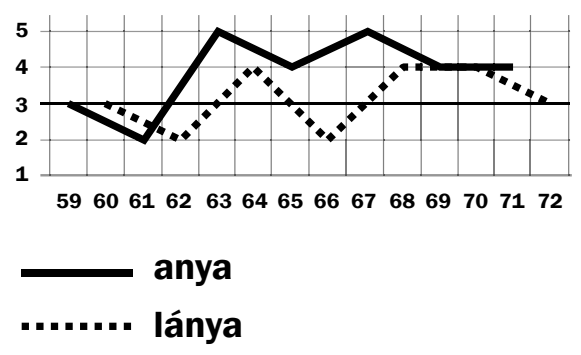

17. ábra. A X-es tábla intimitásdimenziója

Az életük (X. tábla) az anyai biztonságnyújtás ígéretével (anya válaszjavaslata: vár. Vár jelentése: biztonság) ragadhat bele a gyermeki lelkiségbe. Az anya üzenete sorra visszahúzó („hínár”), gyermeki („hidacska”) érzelmi biztonságot ígérô („az egész nagy víz = befogadás”); van életsziget („sziget”) és benne a biztonság („vár ismétlése”) és sok-sok más, „halacska” (élsz, mint hal a vízben). A lány megadó válasza: Ühüm. A szimbiózisból nem tud kitörni, felnôni. A tartalmi üzenetek szimbolikája önmagáért szól. A „Rorschach-nyelv” a mélységekrôl beszél.

\section{ÉRTELMEZÉSI SZINT}

\section{Elemzésünk konklúziója}

1. Az anya-lány kapcsolatban az anya saját dominanciaigényének alárendelôdésbe fordításával gyakorol kontrollt lánya fölött (metakomplementer viszonyminta).

2. A lány megpróbálja érvényesíteni autonómiatörekvéseit (III. tábla).

3. Az anya ôrizni szeretné a szimbiózist (VII. tábla).

4. A viszony felszínén a világ felé kifejezett pozitív érzelmek (X.) mögött ambivalencia, a mélyben pedig ellenségesség (III.) és félelem (VII.) húzódik meg.

Processzometriai vizsgálatunk pszichodinamikai felismerését az alábbiakban összegezhetjük:

A lány, aki érzelmileg többet ad bele a kapcsolatba, de ambivalens, az anyjával szembeni negatív indulataiból (hasítással) öndestruktív irányulású tünetet képez, eleget téve az anyai parancsnak: „Maradj(unk) kislány(ok)!”

A terápiatervezés szempontjából az anya-lánya alrendszer szimbiózisának feloldása, a lány kiszabadulásának elósegítése lehet a célunk, amely csak akkor sikerülhet, ha az anya (lelkileg) fel tud nôni, és megrekedt „kislány-lelkéból” a szexualitást és életet élvezô asszonnyá tud „kiszabadulni”. Vesztesége mindaddig depresszióra prediszponálja, míg lányának (aki a hiányzó férfi/társ-szeretet pótléka is) elengedése kárpótolja valódi társ megtalálásával. Az apa az idôsebb lánnyal „társuló” alrendszerben vigasztalódik, ó is magányos érzelmileg. Az összekuszálódott és patológiás kötésekben rögzült viszonyok felbontásához az „igazi” megoldás eszerint a családterápia lehet. 


\section{ÖSSZEGZÉS}

Elsố (pszeudo) sine morbo párunk esetében a kezdet és a vég kifeszülô kötel(ék)én folyó kötéltáncot kísértük nyomon a tudatelôttes tartalmak üzenetlépéseiben. Az indulás bemutatkozási helyzetének elterebélyesedése (27 egység!) azonban gyanút keltôen sugallta a kapcsolati egyensúly kényes instabilitását, veszélyeztetettségét. A felderített fallikus kollúzió azt is láttatta, hogyan lehetséges - minden civódás, harc ellenére - együtt maradni, milyen szükségleteket elégít ki egymásnál kölcsönösen a pár, amelyek szervítik a kollúziót. A kimenetek ,jóslata” a krízis és törés veszélyét jelezte számunkra.

A második „klinikai esetünk” keretében viszont már arra törekedtünk, hogy a viszonydinamika-elemzést (hogyan kommunikál az édesanya és lánya) végigvezethessük a projekciós folyamaton. Tartalmi szempontból (mit üzennek az érzelmi tudat szintjén, „öntudatlan spontaneitással”) nem teljes az interpretatív, desifrírozó munkánk. Mégis láttatja, hogy az anorexiában az anya nôi mintája nem elegendô ahhoz, hogy lánya szabadon vállalhassa - anyjához hasonlóan - felnôtt nôi mivoltát. A különös, tudattalan üzenet (maradjunk kislányok) az infantilis „nemnélküliség” regresszív töltéseit nyitja meg elốttünk.

A processzometria nem „rutin vizsgáló módszer”. Alkalmazása azon a szinten is jelentôs ökológiai validitással jár, amikor csak a viszonyszerkezet és -folyamat dimenzióban vizsgálódunk. Ha a mélyebbre lépéshez a Rorschach-tartalmak világába is beletanulunk, ritka „kincstárba” juthatunk általa.

A terápiában mindig hipotéziseket ellenôrzünk, finom lépésekkel haladunk elốre (pacing-leading). Ehhez a hipotézisfelállításhoz és ellenôrzéshez jelent különös segítséget a processzometria. Nem „kinyilatkoztat”, hanem rávilágít a mélységre. Mélyebb összefüggések megértéséhez segít bennünket.

\section{IRODALOM}

Bagdy E., Csákvári Zs., Kiss D., Vetier A., \& Vargha A. (2006). Processzometria. In Pár és családi kapcsolatok. Digitális tankönyv. Letöltve: 2019. 10. 12. www.webcreator.hu/tankonyv

Bagdy E., Mirnics Zs., \& Vargha A. (szerk.). Egyén, pár, család. Budapest: Animula.

Bagdy E., Vetier A., Csákvári Zs., Kiss D., Vargha A., \& Bánsági, P. (2006). Processzometria. Interakciós folyamelemzó eljárás a Közös Rorschach próbában. In Bagdy E. (szerk.), Pár-és családi kapcsolatok vizsgálata (5.6. fejezet). Digitális szakkönyv/tankönyv. Budapest: HEFOP Bölcsész Konzorcium.

Labé, L. (1944). Ne vessetek meg. Lányi Viktor fordítása. In Szerb A., Száz vers (p. 41). Budapest: Magvetố Kiadó.

Luban-Plozza, B., \& Dickhaut, H. H. (szerk.) (1998). A Bálint csoportok elméleti és gyakorlati kérdései. Budapest: Animula Kiadó.

Mérei F. (1947). A Rorschach táblák felszólító jellege. Magyar Pszichológiai Szemle, 16(3-4), $115-125$.

Mérei F. (2002). A Rorschach-próba. Budapest: Medicina Kiadó.

Willi, J. (1978). Die Zweierbeziehung Analyse des unbewussten Zusammenspiels in Partnerwahl und Paarkonflikt: Das Kollusions-Konzept. Rowohlt Reinbek bei Hamburg. 


\title{
RELATIONSHIP DYNAMIC PROCESS-ANALYSIS BY PROCESSOMETRY IN SINE MORBO AND CLINICAL CASES
}

\author{
BAGDY, EMỐKE
}

Objective: Introducing the application of processometry for the follow-up of relationship-dynamic processes of couples.

Method: The validated procedure of the Joint Rorschach Examination (JRE) text-elaboration that allows computer-tomographic, layered, precise analysis of unique, single relationship patterns through the process of test protocol interactions. The objective methodological side of elaboration is the computer-based process-monitoring in the three examined dimensions (dominance, collaboration activity and intimacy) on a five-point scale. The interpretative analytic side is linking contents of messages along symbolic meanings. The „how” of communication and content of its message („what does the subject communicate”) jointly contribute to recognition illuminating psychodynamic depth.

Results: the study of two adapted cases, the "phallic collusion" of an apparently sine morbo couple, and the deep, psychodynamic identity of a girl - suffering from anorexia nervosa - with her mother with regard to the fact that it is dangerous for a woman to become an adult. The common denominator of their secret collusion is 'let's stay girls'.

Conclusion: The study provides an opportunity to understand steps and working methods of the analysis. It highlights the couple and family diagnostic significance of JRE in the cognition of (hidden) relationship dynamic actions.

Keywords: Joint Rorschach Test (JRT); processometry, phallic collusion, anorexia nervosa

A cikk a Creative Commons Attribution 4.0 International License (https://creativecommons. org/licenses/by/4.0) feltételei szerint publikált Open Access közlemény, melynek szellemében a cikk bármilyen médiumban szabadon felhasználható, megosztható és újraközölhetô, feltéve, hogy az eredeti szerzố és a közlés helye, illetve a CC License linkje és az esetlegesen végrehajtott módosítások feltüntetésre kerülnek. (SID_1) 